\title{
PENGARUH KEPERCAYAAN DIRI, PENDIDIKAN DAN DUKUNGAN RELASIONAL TERHADAP INTENSI BERWIRAUSAHA MAHASISWA UNTAR
}

\author{
Steven Tanoto dan Nur Hidayah
}

Program Studi S1 Manajemen Fakultas Ekonomi dan Universitas Tarumanagara, Jakarta

Email: steven.115170071@stu.untar.ac.id

\begin{abstract}
The purpose of this research is to examine whether: 1) self-confidence can affect entrepreneurial intention, 2) educational support can affect entrepreneurial intention, 3) relational support can affect entrepreneurial intention. Sample was selected using nonprobability sampling method amounted to 86 respondents of university students in Tarumanagara University. Data were measured by Likert scale and analyzed with processing techniques using SmartPLS 3.0 program. The result of this study shows that 1) self confidence positively had affect on entrepreneurial intention, 2) education support positively had affect on entrepreneurial intention and, 3) relational support had affect on entrepreneurial intention. Several recommendations for research are presented based on conclusions and suggestions on the results of this study.
\end{abstract}

Keywords: Self-confidence, Education, Relational Support and Entrepreneurial Intention.

Abstrak: Tujuan dari penelitian ini adalah untuk menguji apakah: 1) kepercayaan diri dapat mempengaruhi intensi berwirausaha, 2) pendidikan dapat mempengaruhi intensi berwirausaha, 3) dukungan relasional dapat mempengaruhi intensi berwirausaha. Sampel dipilih menggunakan teknik nonprobability sampling dengan jumlah 86 responden mahasiswa di Universitas Tarumanagara. Data diukur dengan skala Likert dan dianalisis dengan teknik proses yang menggunakan program SmartPLS 3.0. Secara keseluruhan, hasil penelitian ini menunjukkan bahwa 1) kepercayaan diri berpengaruh positif terhadap intensi berwirausaha, 2) pendidikan berpengaruh positif terhadap intensi berwirausaha, dan 3) dukungan relasional berpengaruh positif terhadap intensi berwirausaha. Beberapa rekomendasi untuk penelitian disajikan berdasarkan kesimpulan dan saran mengenai hasil penelitian ini.

Kata kunci: Kepercayaan diri, pendidikan, dukungan relasional, dan Intensi Berwirausaha.

\section{LATAR BELAKANG}

Gerba (2012) menyatakan bahwa Kewirausahaan telah dipandang sebagai cara hidup dan sesuatu yang membantu dalam proses berpikir saat mengatasi ancaman dan mengambil tantangan dan peluang. Pada dasarnya, wirausaha yang memainkan peran dalam beberapa dekade terakhir tidak bisa dipaksakan, akan tetapi dapat dipancing dengan melalui banyak cara. Peran seperti itu, yang termasuk tidak terbatas pada generasi baru yang memuat ide, selanjutnya konversi dari ide-ide ini ke bisnis yang menguntungkan, inovasi proses atau metode, generasi pekerjaan massal, dll, baru-baru ini menangkap perhatian dari para sarjana dan pembuat 
kebijakan (Turker dan Selcuk, 2009). Pada tahun 2020 ini dunia sedang gencar gencarnya untuk membimbing dan membangun intensi kaum muda untuk berwirausaha, tentunya semua pihak bergandengan tangan agar semua ini dapat berjalan lancar.

Izquierdo dan Buelens (2008) menunjukkan bahwa kepercayaan diri dapat mempengaruhi intensi berwirausaha karena dapat membuat seseorang berhasil untuk melakukan tugas-tugas tertentu seperti mengidentifikasi peluang bisnis baru, menciptakan produk baru, berpikir kreatif, dan menciptakan ide atau pengembangan baru. Mulyani (2011) mengemukakan bahwa untuk menjadi wirausahawan yang berhasil, seseorang harus memiliki bekal pengetahuan kewirausahaan dan bekal keterampilan kewirausahaan. Ismail (2009), menjelaskan bahwa jika seorang mahasiswa mengetahui bahwa ia memiliki dukungan kuat dari orang tua dan anggota keluarga mereka, dan juga memiliki akses informasi bisnis, kesediaan mereka untuk menjelajah ke bisnis baru akan cenderung meningkat, sehingga dapat meningkatkan kepercayaan diri mereka.

Tujuan dari penelitian ini adalah untuk menguji secara empiris kemampuan prediksi dari kepercayaan diri, pendidikan, dan dukungan relasional terhadap intensi berwirausaha pada mahasiswa Fakultas Ekonomi di Universitas Tarumanagara. Hasil penelitian ini diharapkan dapat menjadi sumber informasi serta bahan referensi bagi masyarakat mengenai pengaruh kepercayaan diri, pendidikan dan dukungan relasional.

\section{KAJIAN TEORI}

Ajzen dan Fishbein (1980) menyatakan bahwa teori yang menjadi dasar dari penelitian ini adalah Theory of Planned Behavior (TPB). Teori yang paling banyak dan paling berhasil diterapkan untuk memprediksi intensi perilaku seseorang untuk menjadi wirausaha adalah Theory of Planned Behaviour (TPB). Theory of planned behavioral tersebut adalah faktor utama dalam menentukan intensi individu dalam melakukan suatu perilaku secara terperinci. Intensi dipengaruhi oleh 3 faktor yaitu, tingkat pada saat masing masing orang merasa baik (positif) atau kurang baik (negatif) dalam bersikap (attitudes), pengaruh sosial yang merupakan dukungan relasional yang berpengaruh pada masing masing orang untuk melakukan atau tidak melakukan pada perilaku (subjective norms), dan perasaan mudah atau kesulitan dalam melakukan suatu perilaku (perceived behavioral control).

Lauster (2002) menyatakan bahwa "self-confidence is a attitude or belief upon self ability that will make a good achievement in the action". Berdasarkan pernyataan tersebut, kepercayaan diri merupakan suatu sikap atau perasaan yakin akan kemampuan diri sendiri sehingga orang yang bersangkutan tidak terlalu cemas dalam tindakan-tindakannya, merasa bebas untuk melakukan hal-hal sesuai keinginan dan bertanggung jawab atas perbuatannya, hangat dan sopan dalam berinteraksi dengan orang lain, memiliki dorongan berprestasi serta dapat mengenal kelebihan dan kekurangannya. (Izquierdo dan Buelens, 2008) menunjukkan bahwa kepercayaan diri merupakan faktor yang berpengaruh secara signifikan terhadap intensi berwirausaha karena dapat membuat seseorang berhasil untuk melakukan tugas-tugas tertentu seperti mengidentifikasi peluang bisnis baru, menciptakan produk baru, berpikir kreatif, dan menciptakan ide atau pengembangan baru. 
Oemar Hamalik (2001), mengemukakan bahwa pendidikan adalah suatu proses dalam rangka mempengaruhi siswa agar dapat menyesuaikan diri sebaik mungkin terhadap lingkungan dan dengan demikian akan menimbulkan perubahan dalam dirinya yang memungkinkannya untuk berfungsi secara kuat dalam kehidupan masyarakat. Gelaidan dan Abdullateef (2017) menunjukkan bahwa pendidikan merupakan faktor yang berpengaruh secara signifikan terhadap intensi berwirausaha karena dengan adanya dukungan pendidikan yang efektif bisa menjadi faktor motivasi yang mendorong mahasiswa untuk menumbuhkan intensi berwirausaha.

Kail (2000), menyatakan bahwa "that relational support is a source of emotional nature and information or assistance given to someone to solve problems and conditions that occur in that person's life". Berdasarkan pernyataan tersebut, maka dukungan relasional adalah suatu sumber yang bersifat emosi dan informasi atau pendampingan yang diberikan ke seseorang dari orang orang di sekitarnya untuk menyelesaikan masalah serta kondisi yang terjadi pada kehidupan seseorang tersebut. Ismail (2009) menunjukkan bahwa dukungan relasional merupakan faktor yang berpengaruh secara signifikan terhadap intensi berwirausaha karena jika seorang mahasiswa mengetahui bahwa ia memiliki dukungan kuat dari orang tua dan anggota keluarga mereka, dan juga memiliki akses informasi bisnis, kesediaan mereka untuk menjelajah ke bisnis baru akan cenderung meningkat, sehingga dapat meningkatkan kepercayaan diri mereka untuk berwirausaha.

Berdasarkan kajian teori yang ada, model kerangka pemikiran intensi berwirausaha pada mahasiswa disajikan secara visual pada Gambar 1 di bawah ini:

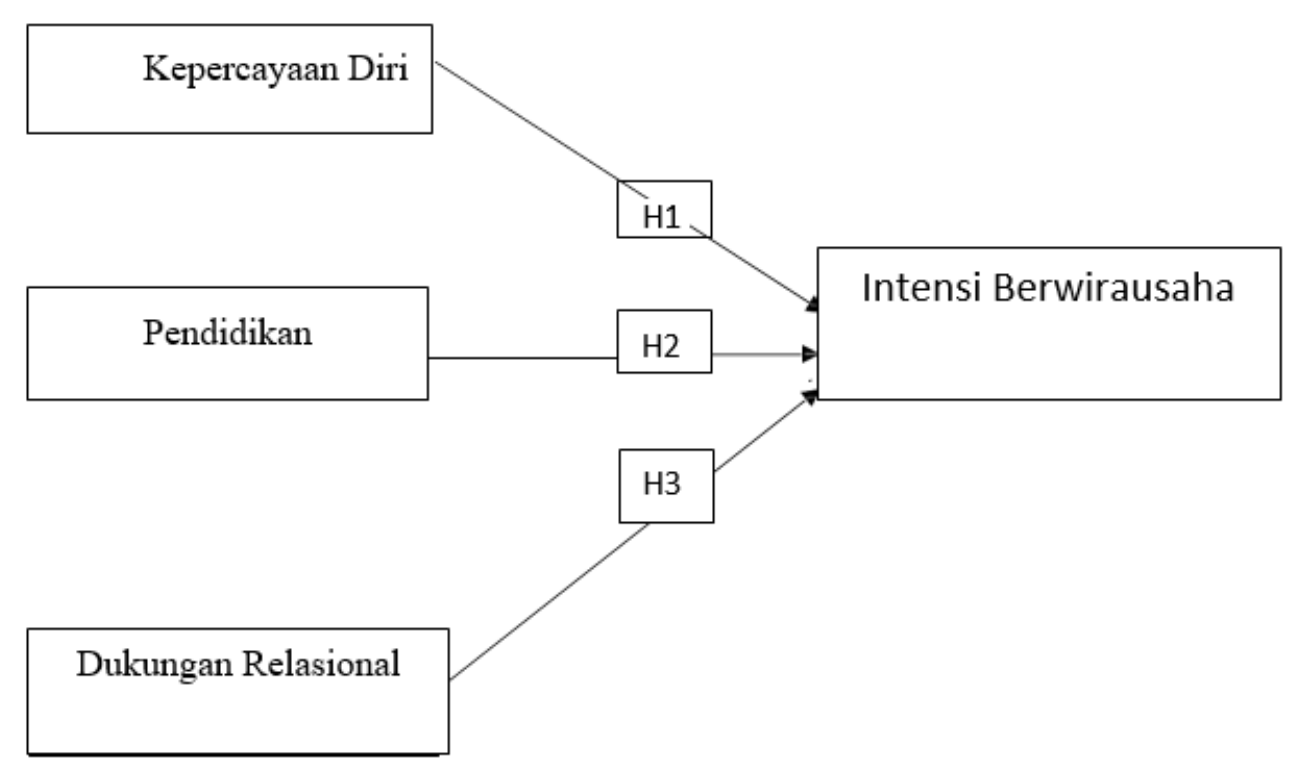

Dari model kerangka pemikiran di atas, hipotesis yang dihasilkan adalah sebagai berikut:

H1 :Terdapat pengaruh positif pada kepercayaan diri terhadap intensi berwirausaha pada mahasiswa Fakultas Ekonomi dan Bisnis Universitas Tarumanagara. 
H2 :Terdapat pengaruh positif pada pendidikan terhadap intensi berwirausaha pada mahasiswa Fakultas Ekonomi dan Bisnis Universitas Tarumanagara.

H3 :Terdapat pengaruh positif pada dukungan relasional terhadap intensi berwirausaha pada mahasiswa Fakultas Ekonomi dan Bisnis Universitas Tarumanagara.

\section{METODOLOGI}

Penelitian ini menggunakan metode penelitian kuantitatif yang bertujuan untuk menjelaskan menentukan hubungan antar variabel dalam sebuah populasi. Populasi yang digunakan dalam penelitian ini adalah mahasiswa Fakultas Ekonomi dan Bisnis Manajemen Universitas Tarumanagara. Penelitian ini menggunakan nonprobability sampling. Sekaran dan Bougie (2016) menyatakan bahwa nonprobability sampling merupakan desain pengambilan sampel di mana elemen-elemen dalam populasi tidak memiliki kesempatan yang diketahui atau ditentukan sebelumnya untuk dipilih sebagai subjek sampel. Malhotra (1993) menyatakan bahwa pengukuran sampel dilakukan untuk mengacu kepada yang memberikan panduan untuk melakukan pengukuran sampel yang nantinya akan diambil dengan cara mengalikan jumlah indikator dengan 5, atau 5x jumlah indikator variabel independen. Penelitian ini mengambil sampel sebanyak 86 responden dengan kriteria yaitu merupakan Mahasiswa aktif dari semester 1-8 Fakultas Ekonomi dan Bisnis Universitas Tarumanagara yang telah mengambil mata kuliah umum dasar-dasar kewirausahaan.

Berdasarkan data yang didapat dari 86 (100\%) responden, sebanyak $54(62,7 \%)$ responden berjenis kelamin wanita dan 32 (37,3\%) responden berjenis kelamin pria. Kemudian, mayoritas responden berusia 20-22 tahun, yaitu sebesar 70 (81\%) diikuti dengan $<20$ tahun sebanyak $8(9.5 \%)$ responden dan 22-25 tahun sebanyak $8(9.5 \%)$ responden. Setiap responden menempuh tingkat semester yang berbeda-beda yaitu yang berada di tingkat semester 7-8 sebanyak 65 (75,5\%) responden, semester 5-6 sebanyak 17 (19,8\%) responden, dan semester 3-4 sebanyak $4(4,7 \%)$ responden. Setiap responden berasal dari berbagai konsentrasi pembelajaran yang berbeda seperti kewirausahaan, pemasaran, sumber daya manusia, keuangan dan yang belum memilih konsentrasi pembelajaran. Setiap responden berasal dari latar belakang keluarga yang berbeda diantaranya wirausaha, pegawai negeri dan pegawai swasta. Kemudian, mayoritas responden berdomisili di Jakarta Barat, yaitu sebesar 59 $(67,9 \%)$ responden diikuti dengan Jakarta Utara sebanyak 15 (17,9\%) responden, Jakarta Pusat, Jakarta Timur dan Jakarta Selatan memiliki jumlah responden yang sama yaitu sebanyak 4 $(4,8 \%)$ responden. Penelitian ini menerapkan penggunaan skala Likert sebagai pemberian skor dari setiap indikator dan penyebaran kuesioner dilakukan secara online melalui internet dengan menggunakan google form. Malhotra (2015) menjelaskan bahwa, skala Likert menunjukkan kategori tanggapan diri para responden dengan tingkat kesepakatan atas rangkaian pernyataan yang terdapat dalam operasional variabel dan instrumen.

\section{HASIL UJI STATISTIK}

Aritonang (2017) menyatakan bahwa Uji validitas adalah suatu instrumen yang digunakan untuk mengukur variabel yang tidak dapat diamati secara langsung (Aritonang, 
2007). Dengan kata lain, instrumen ini dapat mengukur variabel sesuai dengan yang diharapkan. Validitas menyangkut sejauh mana ketepatan dan kecermatan suatu alat ukur dalam melakukan fungsi ukurnya. Uji validitas pada penelitian ini dilihat dari Convergent Validity dan Discriminant Validity. Convergent validity diuji dengan menggunakan loading factor dari setiap indikator dan average extracted variance (AVE) dari setiap variabel.

Tabel 1. Output PLS: Nilai Average Variance Extracted (AVE)

\begin{tabular}{|l|l|}
\hline Variabel & Average Variance Extracted (AVE) \\
\hline Kepercayaan diri & 0.585 \\
\hline Pendidikan & 0.794 \\
\hline Dukungan Relasional & 0.617 \\
\hline Intensi Berwirausaha & 0.677 \\
\hline
\end{tabular}

Sumber: Aplikasi SmartPLS 3.0

Hasil dari AVE menunjukkan nilai sebesar 0,585 untuk variable kepercayaan diri, 0,794 untuk variable pendidikan, 0,617 untuk variable dukungan relasional, dan 0,677 untuk variabel intensi berwirausaha. Hair (2011) menyatakan Hasil ini menunjukkan bahwa setiap variabel di atas telah memenuhi kriteria dengan nilai AVE yang lebih besar dari 0,5. Henseler (2009) menyatakan bahwa suatu indikator dinyatakan valid jika mempunyai loading factor di atas 0.7 terhadap konstruk yang dituju, apabila dalam sebuah model penelitian terdapat indikator yang memiliki nilai loading factor di bawah 0,7, maka indikator tersebut harus dihilangkan. Semua indikator memenuhi kriteria loading factor.

Tabel 2. Output PLS: Nilai Loading Factor

\begin{tabular}{|l|l|c|}
\hline \multicolumn{1}{|c|}{ Indikator } & $\begin{array}{c}\text { Loading } \\
\text { Factor }\end{array}$ \\
\hline KD1 & $\begin{array}{l}\text { Saya dapat melewati rintangan dalam berwirausaha jika memiliki } \\
\text { kepercayaan diri }\end{array}$ & 0,695 \\
\hline KD2 & $\begin{array}{l}\text { Saya memiliki kepercayaan diri dalam berwirausaha karena berlatar } \\
\text { belakang pendidikan bisnis }\end{array}$ & 0,857 \\
\hline KD3 & Saya memiliki optimisme untuk berwirausaha & 0,808 \\
\hline KD4 & Saya tidak ketergantungan dengan orang lain & 0,684 \\
\hline P1 & $\begin{array}{l}\text { Saya menjadi lebih kreatif dalam berwirausaha sejak masuk ke Universitas } \\
\text { Tarumanagara }\end{array}$ & 0,931 \\
\hline P2 & $\begin{array}{l}\text { Saya menjadi lebih terampil berwirausaha sejak masuk ke Universitas } \\
\text { Tarumanagara }\end{array}$ & 0,914 \\
\hline P3 & $\begin{array}{l}\text { Saya mendapatkan pelajaran penting dari pendidikan kewirausahaan di } \\
\text { Universitas Tarumanagara }\end{array}$ & 0,825 \\
\hline DR1 & $\begin{array}{l}\text { Saya berniat untuk berwirausaha karena dukungan dari keluarga dan teman } \\
\text { teman terdekat }\end{array}$ & 0,864 \\
\hline DR2 & $\begin{array}{l}\text { Saya merasa lebih percaya diri dalam berkompetisi karena mendapat } \\
\text { banyak dukungan }\end{array}$ & 0,698 \\
\hline DR3 & $\begin{array}{l}\text { Saya dapat bersemangat dalam menjalani wirausaha karena adanya } \\
\text { dukungan }\end{array}$ & 0,785 \\
\hline
\end{tabular}




\begin{tabular}{|l|l|l|}
\hline IB1 & Saya mempunyai pemikiran ingin berwirausaha & 0,746 \\
\hline IB2 & Saya mempunyai tekad yang besar untuk berhenti menjadi karyawan & 0,829 \\
\hline IB3 & Saya berusaha keras untuk mendirikan bisnis sendiri & 0,888 \\
\hline
\end{tabular}

Sumber: Aplikasi SmartPLS 3.0

Berdasarkan hasil dari Tabel 2, telah menunjukkan bahwa seluruh indikator memiliki nilai loading factor di atas 0,6 di mana telah memenuhi syarat convergent validity, sehingga dapat disimpulkan bahwa semua variabel yang ada dalam penelitian ini telah memenuhi kriteria convergent validity. Dalam pengujian discriminant validity, nilai FornellLarcker yang dimiliki oleh masing-masing variabel pada penelitian ini memenuhi kriteria karena nilai akar kuadrat AVE lebih besar daripada korelasi antar konstruk serta nilai crossloadings masing-masing indikator setiap variabel lebih besar dari nilai cross-loadings variabel lainnya.

Berdasarkan hasil analisis convergent validity maupun discriminant validity, maka dapat disimpulkan bahwa variabel dan indikator yang digunakan dalam penelitian ini valid.

Tabel 3 Output PLS: Nilai Cronbach's Alpha dan Composite Reliability

\begin{tabular}{|l|l|l|}
\hline & Cronbach's Alpha & Composite Reliability \\
\hline Kepercayaan diri & 0.766 & 0.848 \\
\hline Pendidikan & 0.872 & 0.920 \\
\hline Dukungan Relasional & 0.710 & 0.827 \\
\hline intensi berwirausaha & 0.759 & 0.862 \\
\hline
\end{tabular}

Sumber: Aplikasi SmartPLS 3.0

Berdasarkan hasil pengujian reliabilitas pada tabel 3, diketahui bahwa variabel di atas memiliki nilai cronbach's alpha dan composite realibility di atas 0,7. Dengan nilai tersebut, maka dapat disimpulkan bawa data pada penelitian ini reliabel karena memenuhi kriteria dengan hasil yang berada di atas 0,7 (Hair et al., 2011).

Setelah pengujian outer model (validitas dan reliabilitas), pengolahan data variable variabel penelitian dilanjutkan pada tahapan pengujian inner model (model struktural) untuk dapat mengetahui kontribusi dari variabel-variabel independen (X) terhadap variabel-variabel dependen (Y). Kriteria pengujian model struktural yang harus dipenuhi pada penelitian ini yaitu nilai koefisien determinasi (R2 ), predictive relevance (Q2), dan path coefficients.

Hasil nilai koefisen determinasi (R2 ) pada penelitian ini adalah sebesar 0,461, berarti $46,1 \%$ dari variabel dependen yaitu intensi berwirausaha dapat dijelaskan oleh variabel independen yang terdapat pada penelitian ini dan sisanya yaitu sebesar 53,9\% dapat dijelaskan oleh variabel-variabel yang tidak termasuk dalam penelitian ini. Berdasarkan kriteria nilai $R$ Square yang dikemukakan oleh (Cohen, 1988) nilai $R$-Square berada di antara 0,25 dan 0,49 yang artinya memiliki pengaruh lemah. Uji selanjutnya adalah predictive relevance (Q2 ) dengan hasil yang didapatkan sebesar 0,267 (Q2>0). Artinya, variabel penjelas intensi 
berwirausaha yang berupa kepercayaan diri, pendidikan dan dukungan relasional dapat menunjukkan relevansi prediksi yang memadai atau memprediksi model dengan baik. Pengujian berikutnya adalah Goodness of Fit (GoF), dengan hasil sebesar 0,308, (Wetzels et al., 2009) menyebutkan bahwa model yang digunakan pada penelitian ini memiliki tingkat kecocokan yang besar.

Tabel 4. Output PLS: Path Coefficient, $t$ Statistic, dan $p$-Value

\begin{tabular}{|l|l|l|l|}
\hline Hypothesis Relationship & Path Coef. & t Statistics & $\boldsymbol{p}$-Values \\
\hline $\begin{array}{l}\text { H1: Kepercayaan diri } \rightarrow 0.508 \\
\text { Intensi berwirausaha }\end{array}$ & 5.424 & 0.000 \\
\hline $\begin{array}{l}\text { H2: Pendidikan } \rightarrow \text { Intensi0.038 } \\
\text { berwirausaha }\end{array}$ & 0.369 & 0.712 \\
\hline $\begin{array}{l}\text { H3: Dukungan relasional0.223 } \\
\rightarrow \text { Intensi berwirausaha }\end{array}$ & 2.024 & 0.043 \\
\hline
\end{tabular}

Sumber: Hasil Pengolahan data menggunakan software smartPLS versi 3.0

Berdasarkan tabel di atas, hasil pengujian bootstrapping (hipotesis) dari variabel kepercayaan diri dan dukungan relasional terhadap intensi berwirausaha memiliki nilai $t$ statistics $>1,96$ dan nilai $p$-values $<0,05$, sehingga dapat dikatakan bahwa hipotesis 1 dan 3 tidak ditolak dan memiliki arah hubungan yang positif, sedangkan variabel pendidikan terhadap intensi berwirausaha memiliki nilai $t$-statistics $<1,96$ dan nilai $p$-values $>0,05$, sehingga dapat dikatakan bahwa hipotesis 2 ditolak dan memiliki arah hubungan yang tidak positif.

Hasil pengujian hipotesis pertama yang didapatkan untuk variabel kepercayaan diri menunjukkan nilai $t$-statistics sebesar 5,424 dengan $p$-value sebesar 0,000. Nilai tersebut lebih besar dari cut-off value sebesar 1,96 dan p-value yang lebih kecil dari 0,05 sehingga H1 tidak ditolak. Oleh karena itu, dapat disimpulkan bahwa kepercayaan diri berpengaruh secara positif terhadap intensi berwirausaha.

Hasil pengujian hipotesis kedua yang didapatkan untuk variabel pendidikan menunjukkan nilai $t$-statistics sebesar 0,369 dengan $p$-value sebesar 0,712. Nilai tersebut lebih kecil dari cut-off value sebesar 1,96 dan p-value yang lebih besar dari 0,05 sehingga $\mathrm{H} 2$ ditolak. Oleh karena itu, dapat disimpulkan bahwa pendidikan berpengaruh secara tidak positif terhadap intensi berwirausaha.

Hasil pengujian hipotesis ketiga yang didapatkan untuk variabel dukungan relasional menunjukkan nilai $t$-statistics sebesar 2,024 dengan $p$-value sebesar 0,043. Nilai tersebut lebih besar dari cut-off value sebesar 1,96 dan p-value yang lebih kecil dari 0,05 sehingga $\mathrm{H} 3$ tidak ditolak. Oleh karena itu, dapat disimpulkan bahwa dukungan relasional berpengaruh secara positif terhadap intensi berwirausaha. 


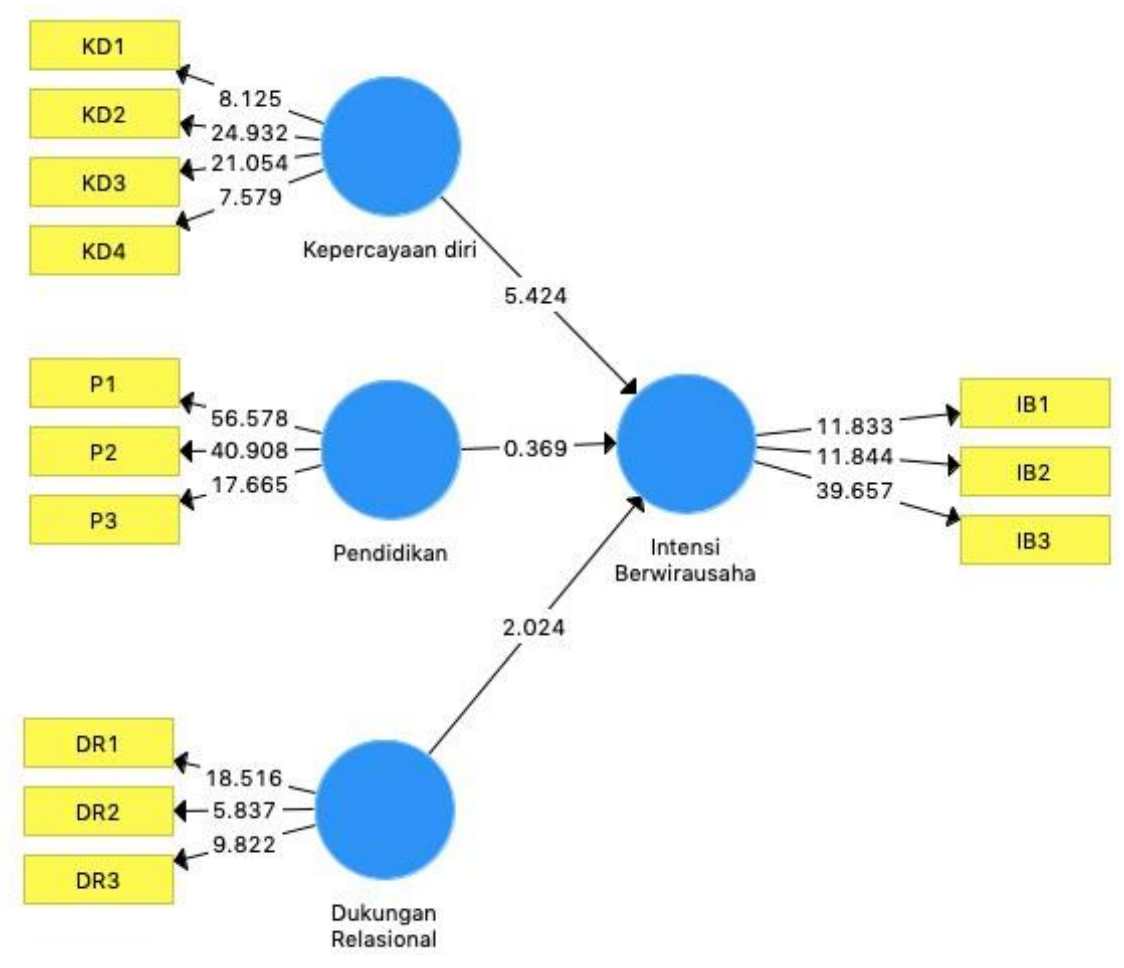

\section{DISKUSI}

Dari analisis data yang telah dilakukan, pengujian pada penelitian ini telah menghasilkan hasil yang sesuai dengan hipotesis terkecuali variabel pendidikan. Hasil dari pengujian hipotesis menunjukkan terdapat pengaruh yang positif dari kepercayaan diri terhadap intensi berwirausaha pada mahasiswa Fakultas Ekonomi dan Bisnis Universitas Tarumanagara. Kemudian, hasil dari pengujian hipotesis dari pendidikan menunjukkan pengaruh yang positif terhadap intensi berwirausaha pada mahasiswa Fakultas Ekonomi dan Bisnis Universitas Tarumanagara yang kemungkinan disebabkan pandemi Covid-19 yang membuat kualitas pendidikan turun, siswa kehilangan kesempatan belajar sebagai mana mestinya. Pada dukungan relasional, hasil pengujian hipotesis menunjukkan bahwa terdapat pengaruh yang positif dari kepercayaan diri terhadap intensi berwirausaha pada mahasiswa Fakultas Ekonomi dan Bisnis Universitas Tarumanagara.

\section{PENUTUP}

Berdasarkan hasil dari keseluruhan pengujian data dalam penelitian ini, telah menunjukkan bahwa kepercayaan diri memiliki pengaruh yang positif terhadap intensi berwirausaha pada mahasiswa. Hal ini sejalan dengan penelitian yang dilakukan oleh Garaika dan Margahana (2019) yaitu kepercayaan diri memiliki pengaruh yang positif terhadap intensi berwirausaha pada mahasiswa. Kemudian, pendidikan tidak berpengaruh secara positif tetapi tidak signifikan terhadap intensi berwirausaha pada mahasiswa Fakultas Ekonomi dan Bisnis Universitas Tarumanagara. Hal ini diduga karena penelitian dilakukan saat COVID 19. Konsultan Nasional Pendidikan dalam Situasi Darurat UNICEF-RDI, Yusra Tebe, menilai pandemi Covid-19 membuat kualitas pendidikan turun, siswa kehilangan kesempatan belajar sebagai mana mestinya (mediaindonesia.com, 2020). 
Selain kepercayaan diri dan pendidikan, dukungan relasional memiliki pengaruh yang positif terhadap intensi berwirausaha pada mahasiswa Fakultas Ekonomi dan Bisnis Universitas Tarumanagara. Dukungan dari teman, orang tua, dan anggota keluarga lainnya akan sangat membantu mereka untuk menjadi seorang wirausaha (Ambad dan Damit, 2016). Seseorang yang menerima dukungan dalam bentuk keuangan, informasi, afeksi, dan moral akan memungkinkan intensi mereka menjadi wirausaha semakin besar dibandingkan dengan orang yang tidak menikmati dukungan tersebut (Ismail et al., 2009).

Dalam sebuah penelitian tentunya dapat memiliki beberapa keterbatasan, begitu pula dalam penelitian ini. Keterbatasan dari penelitian ini dikarenakan: 1) Variabel yang diteliti dalam penelitian ini masih terbilang cukup terbatas yaitu hanya pada tiga variabel bebas dan satu variabel terikat, 2) Sehubungan dengan waktu yang relatif singkat, maka cakupan wilayah yang cukup kecil, menyebabkan responden dari penelitian ini terbatas karena responden yang didapat hanya berasal dari Universitas Tarumanagara.

Berdasarkan hasil dan keterbatasan di atas, maka saran yang dapat diberikan untuk melakukan penelitian selanjutnya adalah selanjutnya dapat menambahkan variable efikasi diri, motivasi berwirausaha atau variabel lain yang berkaitan untuk melengkapi penelitian yang baru. Selain itu, disarankan agar Fakultas Ekonomi dan Bisnis, melakukan penambahan penyelenggaraan kegiatan seperti seminar dan yang lainnya dengan berbagai kolaborasi dengan berbagai pihak baik akademisi, praktisi dan juga pemerintah di universitas karena kegiatan ini dapat membantu mahasiswa untuk memahami pentingnya networking dalam suatu kegiatan dan sharing pengalaman yang dibagikan oleh para narasumber.

\section{DAFTAR PUSTAKA}

Ajzen, I (1991). The Theory of Planned Behavior.Organizational Behavior and Human Decission Processes 50, 179-211. Academic Press,Inc

Baughn, CC, Chua, BL dan Neupert, KE (2006), "Konteks normatif untuk partisipasi perempuan dalam entrepreneruship: a multicountry study", Teori dan Praktek Kewirausahaan, Vol. 30 No. 5, hlm. 687-708.

Bolton, DL dan Lane, MD (2012), "Orientasi kewirausahaan individu: pengembangan instrumen pengukuran ", Pendidikan + Pelatihan, Vol. 54 No. 2/3, hlm. 219-233.

Bray, I., Kenny, G., Pontin, D., Williams, R. dan Albarran, J. (2016), "Kehadiran keluarga selama resusitasi: validasi skala risiko-manfaat dan kepercayaan diri untuk perawat siswa ",Jurnal Penelitian di Keperawatan, Vol. 21 No. 4, hlm. 306-322.

Bougie, \& Sekaran. (2013). Edisi 5, Research Methods for Business: A skill Building Approach. New York: John wiley@Sons

Chin, W. W. (1998). The partial least squares approach for structural equation modeling. in G. A. Marcoulides (Ed.), Modern methods for business research (p295-236). London: Lawrence Erlbaum Associates

Diaz-Garcia, M., \& Jimenez-Moreno, J.(2010). Entrepreneurial Intentions: The Role of Gender. International Entrepreneurship and Management Journal 4(4), 467-83. 
Dinis, A., Paço, AF, Ferreira, J., Raposo, M. dan Rodrigues, RG (2013), "Karakteristik psikologis dan niat kewirausahaan di antara siswa sekolah menengah ", Pendidikan + Pelatihan, Vol. 55 No. 8/9, hlm. 763-780.

Francisco Liñán \& Yi-Wen Chen, 2006. "Testing the Entrepreneurial Intention Model on a Two-Country Sample," Working Papers 0607, Departament Empresa, Universitat Autònoma de Barcelona, revised Jul 2006.

Ismail, M., Khalid, SA, Othman, M., Jusoff, HK, Rahman, NA, Kassim, KM dan Zain, RS (2009), "Niat wirausaha di kalangan mahasiswa Malaysia", International Journal of Business dan Manajemen, Vol. 4 No. 10, hlm. 54.

Karimi, S., Biemans, HJA, Lans, T., Chizari, M. dan Mulder, M. (2016), "Dampak dari pendidikan kewirausahaan: studi tentang niat wirausaha siswa Iran dan identifikasi peluang ", Jurnal Manajemen Bisnis Kecil , Vol. 54 No. 1, hlm. 187-209.

Lee, L., Wong, PK, Chua, BL dan Chen, J. (2005), “Anteseden untuk kecenderungan kewirausahaan: temuan dari Singapura, Hong Kong dan Taiwan".

Robb, AM dan Fairlie, RW (2006), "Menelusuri akses ke modal finansial di antara orang Afrika-Amerika dari usaha kewirausahaan ke bisnis yang mapan ", Research Conference on Kewirausahaan Di Antara Minoritas dan Wanita .

Siu, W., \& Lo, E. S. (2013). Cultural Contingency in the Cognitive Model of Entrepreneurial Intention. Entrepreneurship Theory and Practice 37(2), 147-173.

Solesvik, MZ, Westhead, P., Kolvereid, L. dan Matlay, H. (2012), "Niat siswa untuk menjadi wiraswasta: konteks Ukraina ", Jurnal Bisnis Kecil dan Pengembangan Perusahaan, Vol. 19 No. 3, hlm. 441-460.

Turker, D. dan Selcuk, SS (2009), "Faktor-faktor mana yang mempengaruhi niat kewirausahaan universitas siswa", Jurnal Pelatihan Industri Eropa, Vol. 33 No. 2, hlm. 142-159.

Wilson, F., Kickul, J. dan Marlino, D. (2007), “Gender, self-efficacy kewirausahaan, dan kewirausahaan niat karir: implikasi untuk pendidikan kewirausahaan ", Teori Kewirausahaan dan Berlatih, Vol. 31 No. 3, hlm. 387-406.

Yurtkoru, E. S., Kuşcu, Z. K., \& Doğanay, A. (2014). Exploring the antecedents of entrepreneurial intention on Turkish University students. Procedia-Social and Behavioral Sciences, 150, 841-850. 